\title{
Apakah Endometriosis Mempengaruhi Kualitas Embryo pada Pasien Invitro Fertilization?
}

\author{
Dewanto Suryoningrat ${ }^{1 *}$, Abdurahman Laqif ${ }^{2}$, Soetrisno $^{2}$, Uki Retno Budihastuti ${ }^{2}$, Sri Sulistyowati ${ }^{2}$ \\ ${ }^{1}$ Residen Obstetri dan Ginekologi, Fakultas Kedokteran, Universitas Sebelas Maret, Surakarta, Indonesia \\ ${ }^{2}$ Departemen Obstetri dan Ginekologi, Fakultas Kedokteran, Universitas Sebelas Maret, RSUD Dr. Moewardi, Surakarta, Indonesia \\ Korespondensi: ${ }^{* 1}$ dewanto.suryoningrat@student.uns.ac.id
}

Submisi: 11 Januari 2021; Revisi:5 April 2021; Penerimaan: 7 April 2021

\begin{abstract}
Background: Invitro Fertilization is one of the best management of infertility, but there is still a $50 \%$ similarity of chance of failure of embryo development compared to patients without endometriosis.

Objective: To determine the correlation between endometriosis and embryo quality in patients undergoing invitro fertilization program.

Method: Data of patients who underwent invitro fertilization at the Sekar Fertility Clinic Dr. Moewardi Surakarta in January 2010 - December 2019 was collected from the medical records. The analysis used descriptive test and unpaired T test. Results were considered significant if $p \leq 0.05$.

Results and Discussion: This study showed the mean amount of embryos with good quality had a significant difference $(p<0.05)$ between patients with endometriosis and patients without endometriosis, while the mean amount of embryo with poor quality did not have a significant difference $(p>0.05)$.

Conclusion: Endometriosis has a significant association with embryo quality in women undergoing IVF programs.
\end{abstract}

Keywords: Embryo quality; Endometriosis; invitro fertilization

\begin{abstract}
ABSTRAK
Latar Belakang: Invitro Fertilization merupakan salah satu manajemen infertilitas yang baik, namun masih didapatkan adanya kesamaan peluang kegagalan perkembangan embrio sebanyak $50 \%$ dibandingkan dengan pasien yang tidak mengalami endometriosis.

Tujuan: Untuk mengetahui hubungan endometriosis dan kualitas embrio pada pasien yang menjalani program invitro fertilization.

Metode: Data yang dikumpulkan merupakan data pada rekam medis pasien Klinik Fertilitas Sekar yang menjalani invitro fertilization di Klinik Fertilitas Sekar RSUD Dr. Moewardi Surakarta pada Januari 2010 - Desember 2019. Analisis menggunakan uji deskriptif dan Uji T tidak berpasangan. Hasil dianggap signifikan jika $p \leq 0,05$.

Hasil dan Pembahasan: Dalam penelitian ini, rerata jumlah embrio dengan kualitas baik memiliki perbedaan yang signifikan $(p<0.05)$ antara pasien dengan endometriosis dan pasien tanpa endometriosis, sedangkan rerata jumlah embrio dengan kualitas buruk tidak memiliki perbedaan yang signifikan ( $p>0.05)$.

Kesimpulan: Endometriosis memiliki hubungan yang signifikan dengan kualitas embrio pada wanita yang menjalani program IVF.
\end{abstract}

Kata Kunci: Endometriosis; invitro fertilization; kualitas embrio 


\section{PENDAHULUAN}

Invitro Fertilization (IVF) merupakan salah satu Assisted Reproductie Technology (ART) yang mampu membantu kesuburan pada pasien endometriosis. ${ }^{1}$ Pada tahun 2018 - 2019 terdapat total 284 pasien yang terdiagnosis endometriosis di Rumah Sakit Umum Daerah (RSUD) Dr. Moewardi Surakarta, sedangkan tahun 2010 - 2019 Data di poliklinik Fertilitas Sekar RSUD Dr. Moewardi Surakarta didapatkan bahwa total 119 pasien mengikuti program Invitro fertilization (IVF), 15 diantaranya merupakan pasien endometriosis (Data primer, 2020). Meskipun IVF merupakan salah satu manajemen infertilitas yang baik, namun masih didapatkan adanya kemungkinan kegagalan perkembangan embrio sebanyak 50\% dibandingkan dengan pasien yang tidak mengalami endometriosis. $^{2}$

Endometriosis adalah penyakit ginekologi yang memiliki prevalensi tinggi dan sering dikaitkan dengan infertilitas, bahkan dalam bentuk yang ringan. ${ }^{3}$ Wanita dengan endometriosis memiliki hasil oosit dan tingkat fertilisasi yang lebih rendah dari wanita dengan infertilitas tuba, namun begitu oosit dibuahi, embrio memiliki tingkat peluang implantasi yang sama. ${ }^{4}$ Kemudian hasil penelitian yang dilakukan oleh Cohen et al., (2015) pada model tikus mendukung bahwa endometriosis peritoneum yang diinduksi dalam model tikus dikaitkan dengan penurunan kualitas oosit dan jumlah embrio, sedangkan pada penelitian yang dilakukan oleh Sanchez et al., (2020) dinyatakan bahwa endometriosis tidak mempengaruhi tingkat pembuahan, kualitas embrio tahap pembelahan, dari blastokista dan tingkat blastulasi. ${ }^{5,6}$ Berdasarkan hal tersebut, penelitian ini dilakukan untuk mengetahui hubungan endometriosis dan kualitas embrio yang dihasilkan saat dilakukan IVF di Klinik Fertilitas Sekar RSUD Dr. Moewardi Surakarta.

\section{METODE}

Penelitian analitik deskriptif dengan pendekatan cross sectional menggunakan data sekunder yang dilakukan di Klinik Fertilitas Sekar RSUD Dr. Moewardi Surakarta. Data yang dikumpulkan merupakan data pada rekam medis pasien Klinik
Fertilitas Sekar yang menjalani IVF di Klinik Fertilitas Sekar RSUD Dr. Moewardi Surakarta pada kurun waktu Januari 2010 - Desember 2019. Kriteria inklusi adalah pasien wanita yang mengikuti program Invitro Fertilization (IVF) di Klinik Fertilitas Sekar RSUD Dr. Moewardi Surakarta dan dari hasil pemeriksaan terdiagnosis endometriosis. Pasien yang terdiagnosis dengan Polycystic Ovarian Syndromes (PCOS), BMI >25, wanita usia > 35 tahun, wanita yang hasil pemeriksaan penunjangnya tidak dapat melengkapi data penelitian ini, dan terdapat kelainan spermatozoa akan diekslusikan dari penelitian.

Endometriosis merupakan kelainan ginekologi jinak pada wanita yang ditandai dengan adanya glandula dan stroma endometrium di luar dari tempat semestinya yang telah terdiagnosis secara laparoskopi diagnostik. Karakteristik penilaian terhadap morfologi perkembangan produk hasil fertilisasi secara In Vitro dengan pembagian kriteria kualitas baik, cukup, dan jelek. Kriteria embrio dengan kualitas baik adalah fragmentasi $<10 \%$, ukuran sel spesifik, dan tidak ada multinukleasi. Kriteria embrio dengan kualitas cukup adalah fragmentasi $10-25 \%$, ukuran sel spesifik untuk sebagian besar sel, dan tidak ada bukti multinukleasi, sedangkan kriteria embrio dengan kualitas buruk jika fragmentasi > $25 \%$, ukuran sel tidak spesifik, dan terdapat bukti multinukleasi. Uji univariat dianalisis dengan uji deskriptif. Uji bivariat antar variabel dianalisis dengan uji $T$ tidak berpasangan. Hasil dianggap signifikan jika $p \leq 0,05$.

\section{HASIL DAN PEMBAHASAN}

Penelitian ini memiliki 55 subjek penelitian yang memenuhi kriteria. Berdasarkan tabel 1 didapatkan wanita dengan endometriosis yaitu sebesar 31 pasien $(56.4 \%)$, sedangkan wanita dengan endometriosis sebesar 24 pasien (43.6\%). Sebanyak 34 pasien (61.2\%) berusia 20-29 tahun dan 21 pasien (38.1\%) berusia 20-29 tahun. Pada karakteristik infertilitas, didapatkan proporsi paling banyak pada pasien yang mengalami infertilitas kurang dari 5 tahun yaitu sebanyak 30 pasien (54.5\%), sedangkan pasien infertil lebih dari 5 tahun sebanyak 25 pasien (45.5\%). 
Tabel 1. Karakteristik Sampel

\begin{tabular}{lllll}
$\begin{array}{l}\text { Karakteristik } \\
\text { Endometriosis }\end{array}$ & N & Mean & SD & $\%$ \\
$\quad$ Ya & 24 & & & \\
$\quad$ Tidak & 31 & & & 43.6 \\
Usia & & & & \\
$\quad$ 20-29 tahun & 21 & 27.05 & 2.09 & 38.1 \\
$\quad$ 30-35 tahun & 34 & 33.42 & 1.43 & 61.2 \\
$\begin{array}{l}\text { Infertil } \\
\quad<5 \text { tahun }\end{array}$ & 30 & 2.63 & 0.99 & 54.5 \\
$\quad 25$ tahun & 25 & 7.64 & 2.69 & 45.5 \\
\hline
\end{tabular}

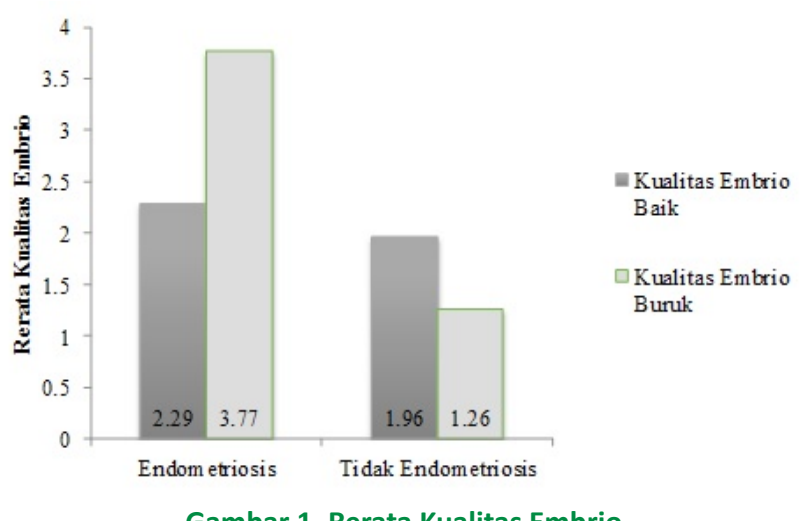

Gambar 1. Rerata Kualitas Embrio

Berdasarkan Gambar 4.1 didapatkan rerata jumlah embrio dengan kualitas baik pada kelompok endometriosis sebesar 2.29, sedangkan jumlah embrio baik pada kelompok tanpa endometriosis memiliki rerata yang lebih besar yaitu 3.77. Kedua kelompok memiliki perbedaan yang signifikan dengan nilai $p=0.026 \quad(p<0.05)$. Jumlah embrio dengan kualitas buruk pada kelompok dengan endometriosis juga memiliki angka yang lebih besar yaitu 1.96, sedangkan pada kelompok tanpa endometriosis sebesar 1.26 , tetapi tidak mengalami perbedaan yang signifikan secara statistik $p=0.215$ $(p>0.05)$. Hasil penelitian ini menunjukkan bahwa terdapat hubungan yang signifikan antar variabel endometriosis dengan kualitas embrio pada wanita yang menjalani program IVF.

Berdasarkan hasil uji deskriptif, didapatkan jumlah kelompok dengan endometriosis sebanyak 24 sampel (43.6\%) dan jumlah sampel tanpa endometriosis sebanyak 31 sampel (54.4\%). Kualitas embrio pada penelitian ini dinilai berdasarkan parameter persentase fragmentasi, ukuran sel spesifik, dan adanya multinukleasi. ${ }^{7}$ Berdasarkan hasil pengamatan pada seluruh subjek didapatkan bahwa beberapa subjek kategori cukup memiliki kemiripan struktur yang sulit dipisahkan dengan kategori baik, sehingga disimpulkan bahwa sampel hanya dapat dikategorikan menjadi baik dan buruk. Kemudian untuk mengetahui hubungan antara kedua variabel penelitian, dilakukan analisis statistik menggunakan uji t-test independen.

Hasil uji analisis data menunjukkan rerata jumlah embrio dengan kualitas baik pada kelompok endometriosis lebih kecil dibandingkan dengan kelompok tanpa endometriosis. Hasil penelitian ini mendukung penelitian yang dilakukan oleh Cohen et al., (2015) yang meneliti model tikus dengan endometriosis peritoneum dan penelitian Boerge $\mathrm{J}$ et al., (2015) yang menilai pengaruh endometriosis dengan perkembangan embrio. Kedua hasil penelitian ini menjelaskan bahwa pasien dengan endometriosis mengalami penurunan kualitas pada oosit dan jumlah embrio. ${ }^{6,8}$ Beberapa penelitian terkait lainnya yang menjelaskan hubungan antara endometriosis dengan kualitas embrio dilakukan oleh Pellicer, et al, (2000). Hasil penelitian tersebut menyebutkan bahwa infertilitas pada pasien dengan endometriosis berkaitan dengan adanya perubahan dalam folikel yang menghasilkan oosit dan embrio dengan kualitas yang lebih rendah pada wanita yang menjalani program IVF. ${ }^{9}$

Seperti yang telah dijelaskan sebelumnya bahwa endometriosis berdampak negatif terhadap kesuburan dan menyebabkan infertilitas karena adanya gangguan pada pengeluaran oosit, gangguan pada embrio, transportasi embrio, dan gangguan pada endometrium. ${ }^{10,11}$ Endometriosis mempengaruhi proses folikulogenesis dengan meningkatkan sistem ROS dan faktor inflamasi yaitu IL-8, IL12 dan adrenomedulin. Gangguan folikulogenesis ini menyebabkan gangguan pada pembentukan morfologi oosit. Endometriosis juga dihubungkan dengan kondisi inflamasi kronis yang akan meningkatkan spesies oksigen reaktif (ROS) sehingga terjadi kelainan meiotik dan ketidakstabilan kromosom sehingga mengurangi kualitas oosit yang terpapar. ${ }^{12}$ 
Dalam penelitian ini, rerata embrio dengan kualitas baik memiliki perbedaan yang signifikan $(p<0.05)$ antara pasien dengan endometriosis dan pasien tanpa endometriosis. Sedangkan kualitas embrio buruk tidak memiliki perbedaan yang signifikan $(p>0.05)$. Hal ini dapat dikarenakan jumlah sampel yang digunakan dalam penelitian ini masih terlalu sedikit, sehingga belum menunjukkan perbedaan yang signifikan. Penelitian ini juga tidak menilai kualitas embrio berdasarkan derajat keparahan endometriosis. Sebuah meta analisis menunjukkan adanya perbedaan signifikan kualitas oosit pada derajat keparahan endometriosis yang berbeda. Penelitian yang dilakukan oleh $\mathrm{Xu}$ et al (2015) menunjukan penurunan kualitas oosit pada pasien dengan endometriosis ringan dan sedang, padahal oosit merupakan faktor yang berperan penting dalam perkembangan embrio. ${ }^{13}$ Namun, rerata kualitas embrio buruk yang lebih tinggi pada kelompok dengan endometriosis dibandingkan dengan kelompok tanpa endometriosis cukup menunjukkan bahwa kualitas embrio pada endometriosis lebih buruk dibandingkan dengan tanpa endometriosis. Pernyataan ini sesuai dengan hipotesis dari peneliti yang menunjukkan bahwa terdapat hubungan antara endometriosis dengan kualitas embrio pada wanita yang menjalani program IVF di RSUD Dr. Moewardi.

Hasil penelitian yang berbeda disampaikan pada penelitian yang dilakukan oleh Sanchez et al., (2020). Penelitian tersebut menyatakan bahwa endometriosis tidak mempengaruhi tingkat pembuahan, kualitas embrio tahap pembelahan, dari blastokista dan tingkat blastulasi. ${ }^{5}$ Penelitian Al-Fadhli R, et al., (2006) yang menilai pengaruh derajat endometriosis dengan keberhasilan program IVF, juga menjelaskan bahwa adanya endometriosis, termasuk stadium III dan IV, tidak mempengaruhi hasil kualitas oosit dan jumlah embrio pada pasien yang menjalani program IVF. ${ }^{14}$

Penelitian Sanchez et al., (2020) menjelaskan bahwa pasien dengan endometriosis terutama yang terjadi di ovarium memiliki pengaruh yang signifikan terhadap kualitas embrio dan oosit pada pasien yang menjalani program IVF. Jika endometriosis terjadi diluar ovarium, bisa jadi pengaruh terhadap penurunan kualitas oosit dan jumlah embrio tidak signifikan. ${ }^{5} \mathrm{Hal}$ ini juga menjadi salah satu kelemahan dalam penelitian ini, yaitu kriteria endometriosis tidak dijelaskan secara rinci mengenai letaknya. Sehingga penelitian lanjutan yang lebih rinci diperlukan untuk mengetahui hubungan antara endometriosis pada ovarium dan diluar ovarium terhadap kualitas embrio pada program IVF.

\section{KESIMPULAN DAN SARAN}

Hasilpenelitian inimenunjukkanbahwa endometriosis memiliki hubungan yang signifikan dengan kualitas embrio pada wanita yang menjalani program IVF. Rerata jumlah embrio dengan kualitas baik lebih tinggi pada kelompok tanpa endometriosis dibandingkan dengan kelompok dengan endometriosis.

\section{DAFTAR PUSTAKA}

1. Evans, M. B. and Decherney, A. H. 'Fertility and Endometriosis'. Clinical Obstetrics and Gynecology. 2017; 60(3): pp. 497-502.

2. Jamaan T., Boediono A., Pakasi T A., Moeloek F A., 'Improving the probability of pregnancy in endometriosis cases: A study in patients undergoing in vitro fertilization'. Medical Journal of Indonesia. 2012; 21(3): pp. 147-151.

3. Da Broi, M. G., and Navarro, P. A. 'Oxidative stress and oocyte quality: ethiopathogenic mechanisms of minimal/mild endometriosis-related infertility'. Cell and Tissue Research. 2016; 364(1).

4. Singh, N., Lata, K., Naha, M., Malhotra, N., Tiwari, A., Vanamail, P. 'Effect of endometriosis on implantation rates when compared to tubal factor in fresh non donor in vitro fertilization cycles'. Journal of Human Reproductive Sciences. 2014; 7(2): pp. 143-147.

5. Sanchez, Ana M., Pagliardini, L., Cermisoni, Greta C., Privitera, L., Makieva, S., Alteri, A., et al. 'Does endometriosis influence the embryo quality and/or development? Insights from a large retrospective matched cohort study', Diagnostics. 2020; 10(2).

6. Cohen, J., Ziyyat, A., Naoura, I., Chabbert-Buffet, N., Aractingi, S., Darai, E., \& Lefevre, B. Effect of induced peritoneal endometriosis on oocyte and embryo quality in a mouse model. Journal of Assisted Reproduction and Genetics 2014, 32(2), 263-270. 
7. Gardner, D. K. and Balaban, B. 'Assessment of human embryo development using morphological criteria in an era of time-lapse, algorithms and "OMICS": Is looking good still important?'. Molecular Human Reproduction 2016; 22(10): pp. 704-718.

8. Borges, E., Braga, D. P., Setti, A. S., Figueira, R. C., Pasqualotto, F. F., \& laconelli, A 'The influence of endometriosis on oocyte quality and embryo developmental competence'. Fertility and Sterility. 2015; 104(3): pp. e201-e202.

9. Pellicer A, Albert C, Garrido N, Navarro J, Remohí J, Simón C. The pathophysiology of endometriosisassociated infertility: follicular environment and embryo quality. Journal of Reproduction and fertility. Supplement. 2000; 55: 109-119.

10. Chapron, C. Marcellin L., Borghese B., Santulli $P$ 'Rethinking mechanisms, diagnosis and management of endometriosis'. Nature Reviews Endocrinology. Springer US. 2019; 15(11): pp. 666-682.
11. Donnez J, Donnez O, Orellana R, Binda MM, Dolmans MM. Endometriosis and infertility. Panminerva Med. 2016; 58(2): 143-150.

12. Sanchez, A M., Vanni, V S., Bartiromo, L., Papaleo, E., Zilberberg, E., Candiani, M., et al. 'Is the oocyte quality affected by endometriosis? A review of the literature'. Journal of Ovarian Research. 2017; 10(1): pp. 1-11.

13. Xu, B., Guo, N., Zhang, X., Shi, W., Tong, X., Iqbal, F., \& Liu, Y. 'Oocyte quality is decreased in women with minimal or mild endometriosis'. Scientific Reports. 2015; 5: pp. 1-8.

14. Al-Fadhli, R., Kelly, S. M., Tulandi, T., \& Lin Tan, $S$ 'Effects of Different Stages of Endometriosis on the Outcome of In Vitro Fertilization', Journal of Obstetrics and Gynaecology Canada. Elsevier Masson SAS. 2006; 28(10): pp. 888-891. 